\title{
PERANCANGAN SISTEM INFORMASI MEDIA BELAJAR PADA SISWA SEKOLAH DASAR BERBASIS RFID
}

\author{
Sepsa Nur Rahman ${ }^{1}$ \\ Eva Rianti ${ }^{2}$
}

\begin{abstract}
This study was conducted to make RFID applications as learning media information System in primary school students. This system is made by designing, making and implementing the components of the system which includes a microcontroller as process controllers, sound modules WTV as output which wil Igenerate. This system also uses RFID as input, where before the tool RFID function should be brought closer to the first RFID TAG and its output on the $L C D$. The results show a tool created to function properly and can be developed to a larger scale.
\end{abstract}

Keywords : RFID, Sensors, Arduino, Sound Module ISD020

\section{INTISARI}

Penelitian ini dilakukan untuk membuat aplikasi RFID sebagai system informasi media belajar pada siswa sekolah dasar. Sistem ini dibuat dengan merancang, membuat dan mengimplementasikan komponen-komponen sistem yang meliputi mikrokontroler sebagai pengendali proses, modul suara WTV sebagai output dimana akan menghasilkan. Sistem ini juga menggunakan RFID sebagai input, dimana sebelum alat berfungsi RFID harus didekatkan dulu ke TAG RFID dan keluaran nya di LCD. Hasil penelitian menunjukkan alat yang dibuat dapat berfungsi dengan baik dan dapat dikembangkan untuk skala yang lebih besar.

Kata Kunci : RFID, Sensor, Arduino, Modul Suara ISD020

\footnotetext{
1,2 Universitas Putra Indonesia "YPTK" Padang
} 


\section{PENDAHULUAN}

Peranan seorang guru dalam proses belajar-mengajar sangatlah penting. Beberapa peranan seorang guru adalah mendidik, mengajar dan membimbing siswa agar siswa bisa mendapatkan hasil yang memuaskan dan yang di inginkan oleh orang tua siswa. Ketika guru tidak masuk dan ada halangan lainnya akibatnya siswa-siswa tidak dapat belajar dengan beberapa mata pelajaran karena pada umumnya disekolah dasar satu guru memengang banyak mata pelajaran. Selain itu guru juga memegang banyak mata pelajaran sehingga guru bisa mengalami kesulitan ketika membawa alat-alat yang akan menjadi bahan ajar.

Cara mengajar guru sekolah dasar pada saat sekarang yaitu dapat kita lihat dalam mengajar guru hanya menjelaskan satu kali saja sehingga murid mudah lupa dengan pelajaran pada saat diajarkan oleh guru dan ditanya dilain hari. Selain itu dengan cara mengajar guru yang hanya mengajar dengan buku dan diajarkan hanya satu kali siswa banyak yang tidak tertarik dan akibatnya siswa tidak mengerti dengan apa yang dijelaskan oleh guru. Pada penelitian ini penulis mengambil contoh mata pelajaran ilmu pengetahuan alam dan matematika dianggap sangat sulit dipelajari oleh siswa sekolah dasar. Pada saat praktek guru juga hanya melihatkan dibuku saja sehingga siswa sulit untuk memahami tentang apa fungsi dari organ tubuh manusia itu sendiri, begitu juga dengan pelajaran matematika yang ingin diketahui siswa. Pembelajaran pratikum khususnya ilmu pengetahuan alam siswa dapat belajar sendiri tanpa ada guru didalam kelas atau labor dengan menggunakan sistem yang akan dibuat. Selain itu pada sistem ini siswa juga dapat belajar matematika sendiri, contohnya adalah saat siswa belajar rumus-rumus seperti rumus mencari luas segitiga, trapesium, bola, dan lain sebagainya, siswa dapat dengan mudah belajar dengan menggunakan sistem ini.

\section{PENDEKATAN DAN PEMECAHAN MASALAH}

Dari latar belakang di atas, dalam melakukan penelitian ini dapat dirumuskan permasalahan yang akan di selesaikan yaitu :

1. Bagaimana perancangan sistem belajar dimana media pembelajaran yang berbasis RFID dengan menampilkan suara dan tulisan dengan menggunakan Mikrocontroller?

2. Bagaimana bahasa pemrograman C dengan program Code Vision AVR bekerja sebagai program pada system pratikumyang berbasis RFID?

3. Bagaimana cara kerja RFID sebagai input yang digunakan untuk menampilkan output suara dan tulisan?

4. Bagaimana cara kerja modul suara yang digunakan untuk menampilkan suara?

5. Bagaimana cara kerja LCD untuk menampilkan tulisan?

\section{Mikrokontroler ATMega32}

ATMega32 merupakan salah satu mikrokontroler 8 bit buatan Atmel untuk keluarga AVR yang diproduksi secara masal pada tahun 2006. Karena merupakan keluarga AVR, maka ATMega32 juga menggunakan arsitektur RISC. Berbeda dengan mikrokontroler keluarga MCS-51 yang berteknologi CISC (Complex Instruction Set Computing). Pada mikrokontroler dengan teknologi RISC semua instruksi dikemas dalam kode 16 bit (16 bits words) dan sebagian besar instruksi dieksekusi dalam 1 clock, sedangkan pada teknologi CISC seperti yang diterapkan pada 
mikrokontroler MCS-51, untuk menjalankan sebuah instruksi dibutuhkan waktu sebanyak 12 siklus clock. Mikrokontroler

AVR ATMega32 memiliki fitur yang cukup lengkap. Mikrokontroler AVR ATMega32 telah dilengkapi dengan ADC internal, EEPROM internal, Timer/Counter, PWM, analog comparator, dll (M.Ary Heryanto, 2008). Sehingga dengan fasilitas yang lengkap ini memungkinkan mempelajari mikrokontroler keluarga AVR dengan lebih mudah dan efisien, serta dapat mengembangkan kreatifitas penggunaan mikrokontroler ATMega32.

\section{Blog Diagram ATMega32}

Pada bagian ini digambarkan blok diagram yang terdapat pada piranti mikrokontroler seperti pada gambar 1.

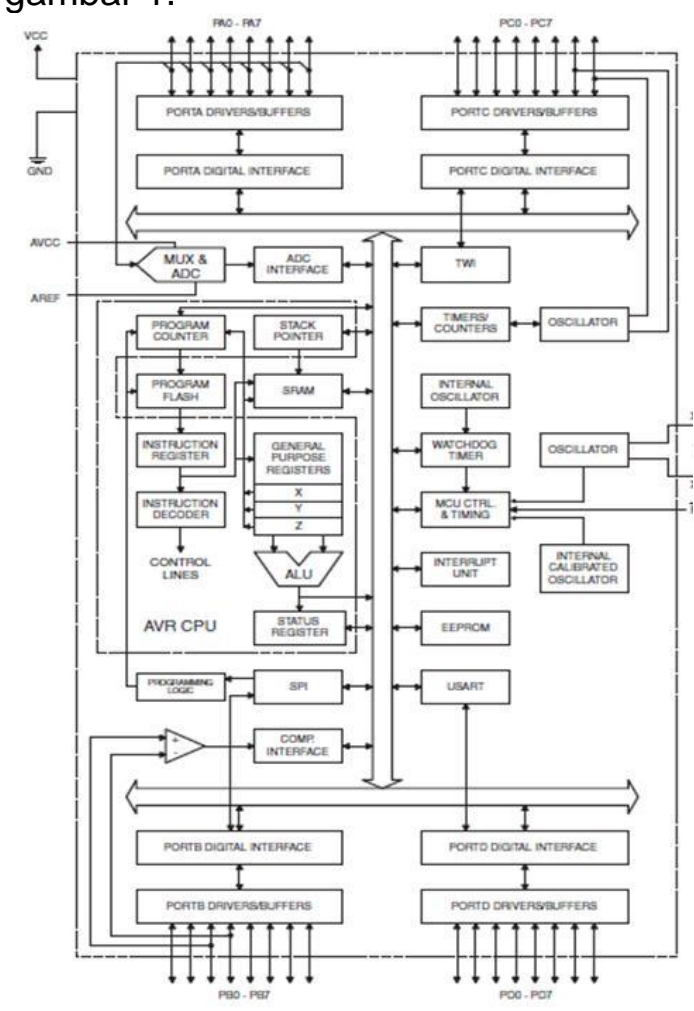

Gambar 1. Blok Diagram Mikrokontroler ATMega32
Konfigurasi Pin ATMega32

Susunan

mikrokontroler

pin-pin

diperhatikan pada gambar 2 Penjelasan masing-masing pin sebagai berikut :

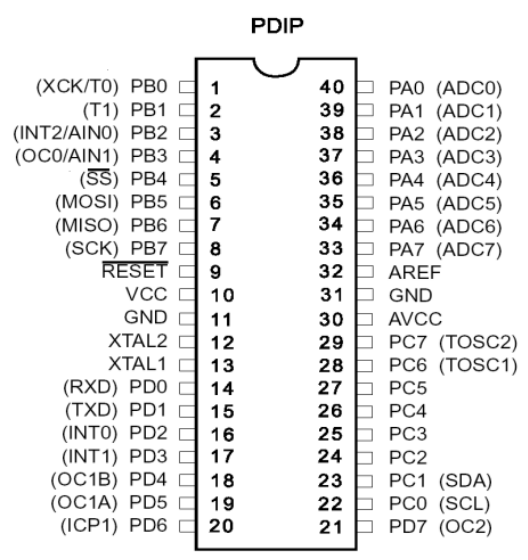

\section{Gambar 2. Susunan Pin (Kaki) Mikrokontroler ATMega32}

1. Vcc : Tegangan supply, merupakan pin yang berfungsi sebagai masukan catu daya.

2. GND : Ground, merupakan pin Ground.

3. Port A (PA7 .. PAO) : merupakan pin input/output dua arah dan pin masukan ADC. Port A digunakan sebagai input analog ke ADC, kemudian port ini juga berfungsi sebagai sebuah port I/O bidireksional 8bit, jika ADC tidak digunakan port pin berfungsi sebagai resistor pull-up internal (dipilih untuk setiap bit).

4. Port B (PB7 .. PBO): merupakan pin input/output dua arah dan dan pin fungsi khusus. Port I/O 8-bit dengan pull-up internal tiap pin. Khusus PB7 dapat digunakan output kristal (output inverting oscillator amplifier) bergantung pada pengaturan fuse bit yang digunakan untuk memilih sumber clock.

5. Port C (PC5 .. $P$ PC) : merupakan pin input/output dua arah dan pin fungsi khusus. Port I/O 7-bit ([PC6], PC5...PC0) 
dengan resistor pullup internal tiap pin. Buffer portC mempunyai kapasitas menyerap (sink) dan mencatu (source).

6. Port D (PD7 .. $P D 0)$ : merupakan pin input/output dua arah dan pin fungsi khusus. Port I/O 8-bit dengan resistor pull-up internal tiap pin. Buffer portC mempunyai kapasitas menyerap (sink) dan mencatu (source).

7. RESET/PC6 : merupakan pin yang digunakan untuk me-reset mikrokontroler. Jika fuse bit RSTDISBL di "programmed", PC6 digunakan sebagai pin I/O. Jika fuse bit RSTDISBL di "unprogrammed", $\quad$ PC6 digunakan sebagai pin RESET (active low).

8. $\boldsymbol{A}$ Vcc : merupakan pin masukan tegangan untuk ADC. adalah pin tegangan catu untuk $A / D$ converter, PC3..PC0, dan $\mathrm{ADC}(7 . .6)$. AVcc harus dihubungkan ke Vcc, walaupun ADC tidak digunakan. Jika ADC digunakan, maka AVcc harus dihubungkan ke Vcc melalui "low pass filter". Catatan: PC5, PC4 digunakan catu tegangan Vcc digital.

9. $\boldsymbol{A R E F}$ : merupakan pin tegangan referensi analog untuk ADC

10. AGND: Ground analog.

11. XTAL1 dan XTAL2: merupakan pin masukan clock eksternal.

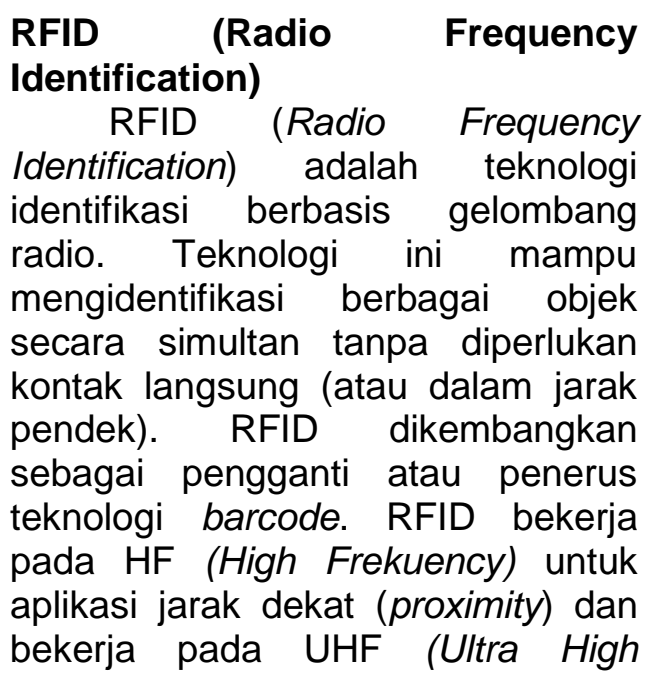

Frekuency) untuk aplikasi jarak jauh (vicinity).

Sensor RFID adalah sensor yang mengidentifikasi suatu barang dengan menggunakan frekuensi radio. Sensor ini terdiri dari dua bagian penting: transceiver (reader) dan transponder (tag). Setiap tag tersimpan data yang berbeda. Data tersebut merupakan data identitas tag. Reader akan membaca data dari tag dengan perantara gelombang radio. Pada reader biasanya berhubungan dengan suatu mikrokontroler. Mikrokontroler ini berfungsi untuk mengolah data yang didapat reader.

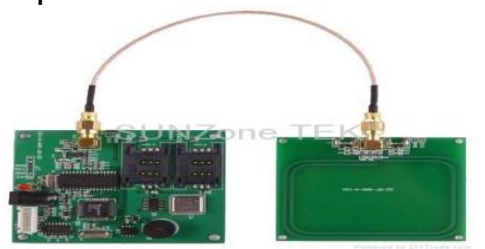

\section{Gambar 3. RFID Reader}

Ketika RFID tag melewati daerah scanning, RFID reader akan mendeteksi sinyal dan mengaktifkan chip pada RFID tag.

\section{Modul Suara ISD 2560}

IC ISD2560 sudah cukup terkenal sebagai IC perekam yang handal dan praktis. Salah satu kelemahan IC ini adalah tidak dapat memutar ulang hasil rekaman menurut pengalamatan / addresing dengan tepat. Memang ISD2560 menawarkan fitur Address Mode, akan tetapi kita tidak dapat memastikan secara pasti rekaman suara pertama, kedua, ketiga, dst berada di kisaran alamat yang mana. Sebagai penghasil suara, gunakan speaker kecil yang biasa digunakan pada mobil maninan anak-anak atau speaker 3 inch 4ohm. Sedangkan untuk urusan input suara, gunakan condensor mic yang dapat mudah ditemukan di toko penjual komponen elektronika. 


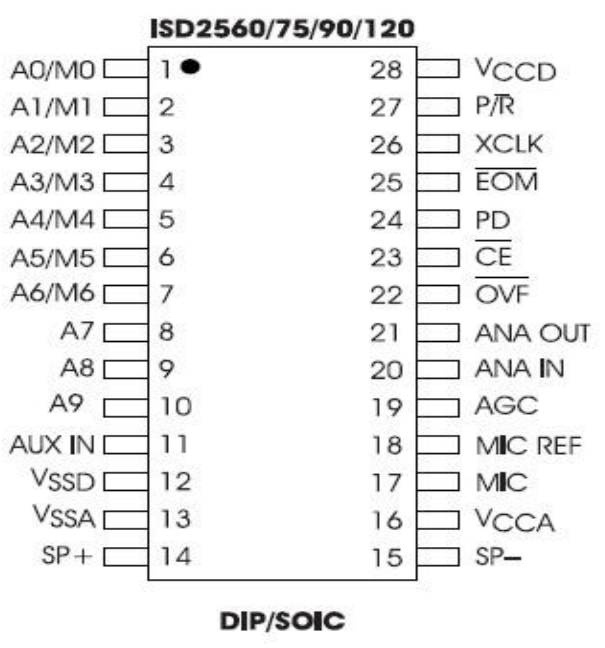

\section{Gambar 4. Konfigurasi pin} ISD2560

Rangkaian ini didesain agar proses input "Play", "Record", "Stop", "Pause" sepenuhnya dikendalikan oleh mikrokontroler. Perihal konfigurasi pin A0-A9, konfigurasi ini merupakan konfigurasi agar ISD2560 bekerja dengan mode "Operational Mode" Berikut ini penjelasan singkat tentang konfigurasi pin A0-A9. Address/Mode Inputs : Fungsi dari pin2 ini adalah mengatur jenis pengeporasian ISD2560. Pengaturan jenis pengoperasian IC ini sepenuhnya dikendalikan oleh bit MSB (bit ke-8 dan bit ke-9 / A8 dan A9).

Apabila kedua pin tersebut terhubung ke sinyal GND, maka IC ISD2560 akan masuk ke menu Address Mode dan fungsi dari pin A0 - A7 sebagai input alamat. Apabila kedua pin tersebut terhubung ke sinyal VCC, maka IC ISD2560 akan masuk ke menu Operational Mode dan fungsi dari pin A0-A7 sebagai input untuk pemilihan mode kerja.

\section{Context Diagram}

Untuk

penganalisaan dalam memudahkan perrasalahan perlu dahulu dilakukan pendefinisian secara menyeluruh terhadap sistem yang dirancang. Context diagram tersebut terdiri atas sebuah proses yang disebut "Sistem Informasi media pembelajaran pada siswa sekolah dasar" dan diberi label 0 . Proses terealisasi dengan beberapa eksternal entity. Context diagram yang dimaksud dapat dilihat pada gambar 4.

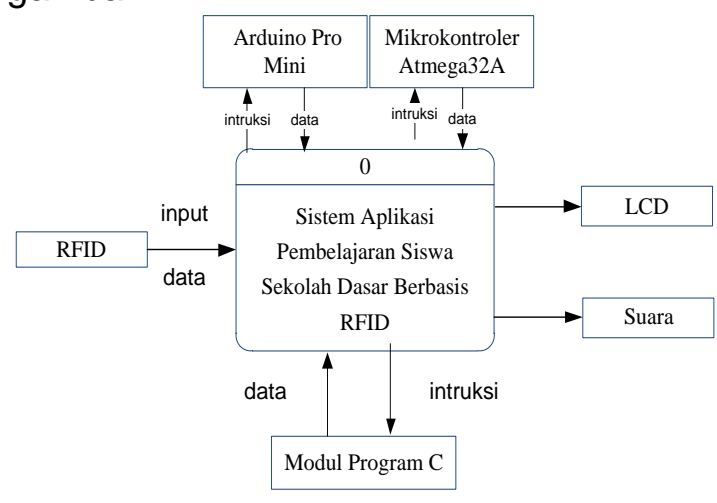

\section{Gambar 5. Context Diagram}

Dari gambar tersebut terlihat bahwa proses terintegrasi dengan 7 eksternal entity, yang dapat diuraikan sebagai berikut :

1. RFID

RFID ini digunakan untuk membaca kartu RFID yang masuk sebagai objek.

2. Arduino Pro Mini

Merupakan piranti pengontrolan dari RFID.

3. Mikrokontroler Atmega32A

Merupakan piranti pengontrolan suara.

4. Modul Program C

Digunakan untuk mengontrol system dari Atmega32A, untuk mengontrol suara pada modul WTV.

5. LCD $4 \times 20$

Berfungsi sebagai keluaran dari sistem untuk menampilkan data pembacaan RFID.

6. Suara

Berfungsi sebagai keluaran berupa suarauntuk menandakan kartu terbaca oleh RFID. 


\section{Data Flow Diagram (DFD)}

Data flow diagram adalah aliran data dari alat yang dibuat. Data flow diagram yang digunakan adalah data flow diagram level 0 karena hanya satu sistem saja yang dikembangkan. Untuk lebih jelasnya dapat dilihat pada gambar dibawah ini:

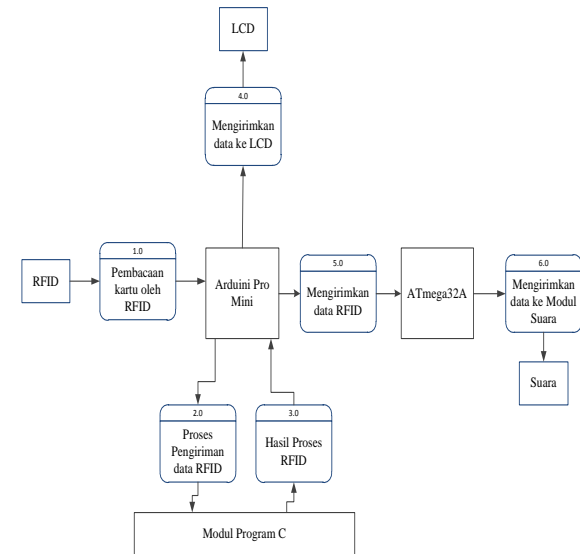

Gambar 6. Data Flow Diagram

Penjelasan proses tersebut dapat diuraikan sebagai berikut : pertama kartu chip adalah sebagai objek dimana kartu chip tersebut terdapat no ID yang di tag kan pada RFID (Radio Frequention Identification) pendeteksian dibaca RFID reader pada blok Pendeteksian Masukan (1.0) berupa signal digital melalui gelombang elektomagnetik, terhubung ke Port C pada Arduino, kemudian signal digital tersebut yang akan di kirim dari Arduino ke Atmega32A. Setelah data terkirim ke Atmega32A, pengolahan data dari hasil pembacaan RFID (3.0) di proses oleh modul program $\mathrm{C}$.

Hasil olah data (3.0) yang telah diolah pada modul program bahasa C, berupa instruksi instruksi untuk menampilkan tampilan pada LCD (4.0) yang sinyal pengirimnya berupa sinyal digital melalui pin 2, 3, 4, 5, 11, 12, vcc dan gnd. Pin - pin tersebut akan dipakai untuk penampilan pada LCD yang berupa data 8 bit (D0 - D7). Mikrokontroler akan memberi output pada suara yang akan mengirim perintah suara berupa fungsi dari kartu yang telah di deteksi(5.0).

\section{Blok Diagram}

Dari rancangan fisik alat maka dapat digambarkan blok diagram peralatan sebagai berikut.

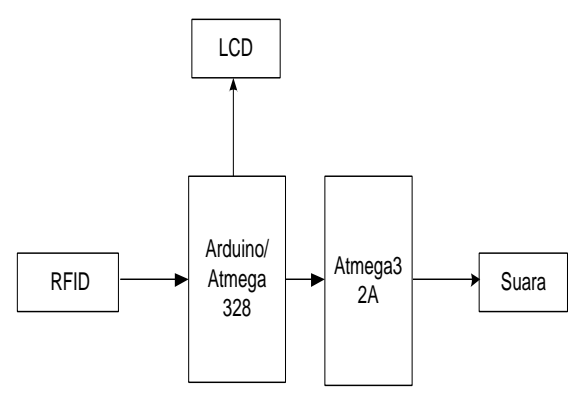

\section{Gambar 7. Blok Diagram}

Radio frequensi Identifikasi (RFID) terdapat tag yang fungsinya untuk menangkap gelombang elektromagnetik yang dibaca oleh RFID reader. Setelah diproses data kembali dikirim pada Arduino yang akan ditampilkan pada LCD menggunakan bahasa C. Data tersebut terhubung pada 8 bit LCD yaitu D0 - D7 untuk penampilan pada layar LCD dalam kedaaan standby ataupun dalam keadaan menerima data juga menampilkan nama dari organ tubuh atau rumus dari phytagoras.

\section{Cara Kerja Alat}

Pada alat ini sistem bekerja secara otomatis dimana sistem bekerja tampa adanya kendali atau kontrol dari luar sistem, kendali keseluruhan sistem dilakukan atau dikendalikan melalui mikrokontroler dan arduino. Pengaturan text pada LCD, RFID sebagai input, mikrokontroler dan arduino sebagai pengendali dan modul suara sebagai keluaran suara dari sistem.

Cara kerja Alat : 
1. Settingan RFID pada Arduino ada dalam prgram yang kita buat.

2. RFID yang ada pada organ tubuh akan melakukan pendeteksian terhadap Tag RFID.

3. Setelah pendeteksian dilakukan oleh RFID, Selanjutnya hasil dari deteksi dikirim ke mikrikontroler.

4. Kemudian Arduino dan Mikrokontroler akan mengirim hasil pendeteksian ke LCD.

5. Terakhir yaitu keluaran yaitu akan berbunyi fungsi dari organ tubuh yang didekatkan pada RFID.

\section{Rangkaian Sistem Minimum}

Sistem minimum merupakan rangkaian minimum yang digunakan untuk mengaktifkan mikrokontroller. Blok rangakaian dari sistem minimum ATMega328 dapat dilihat pada gambar 3.6 berikut ini.

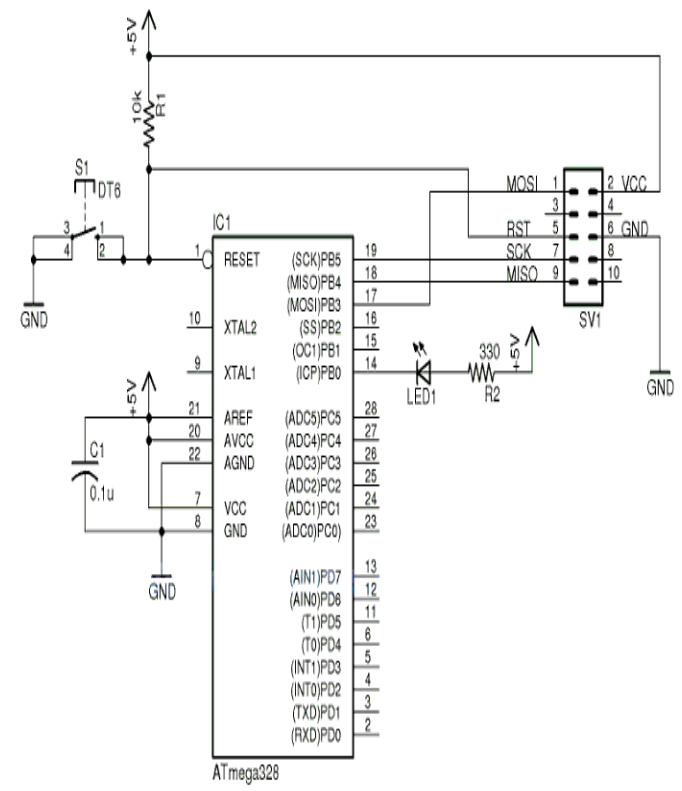

\section{Gambar 8. Rangkaian Sistem} Minimum.

Rangkaian sistem minimum berfungsi untuk menjalankan mikrokontroller agar dapat bekerja sesuai dengan yang kita butuhkan dimana perancangannya bertujuan untuk mempermudah penggunaan mikrokontroler tersebut.

\section{Rangkaian LCD}

Sistem ini menggunakan rangkaian LCD yang fungsinya menampilkan data suhu ruangan yang sesuai dengan instruksi dari modul program.

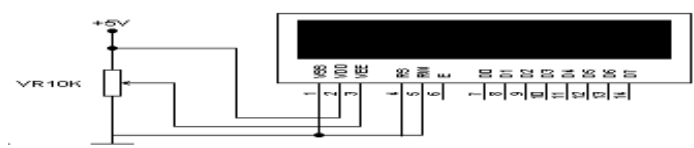

Gambar 9 Rangkaian LCD

Pada rangkaian di atas dapat dilihat bahwa pin 15 ke Vcc dan pin 16 ke Ground ke Arduino, yang mana fungsinya sebagai catu daya yang masuk pada LCD, LCD sendiri memiliki memori dan prosesor tersendiri yang mana apabila data yang telah selesai dikirim dari mikrokontroler maka LCD akan menampilkan karakter sesuai dengan instruksi dan selanjutnya LCD siap menerima data kembali.

\section{Rangkaian WTV020}

Sistem ini menggunakan modul suara jenis WTF020 yang berfungsi sebagai output suara yang akan dikeluarkan setelah tag rfid terdeteksi.

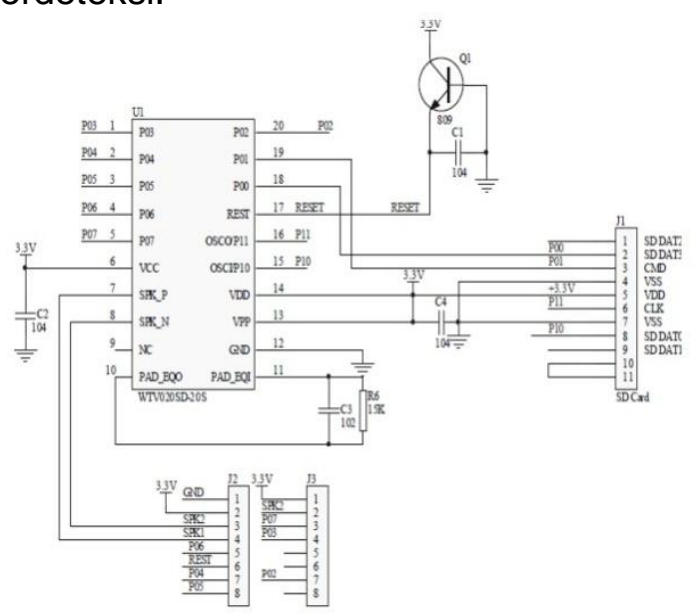

Gambar 10. Rangkaian WTV020 


\section{Flowchart}

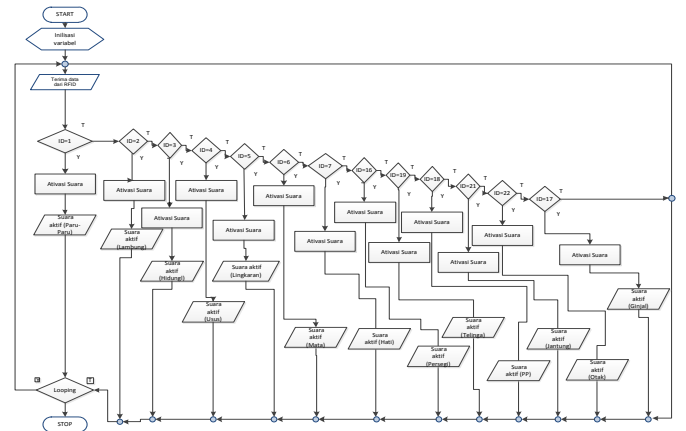

\section{Gambar 11. Flowchart ATmega32}

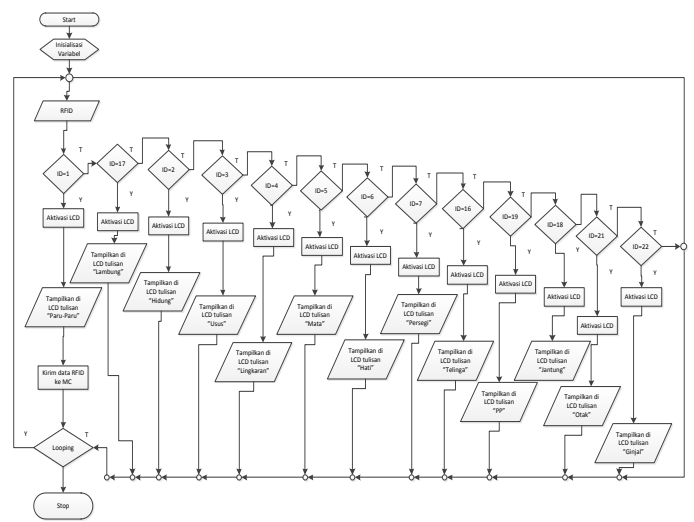

\section{Gambar 12. Flowchart Arduino Pro Mini}

\section{Rancangan Modul Program}

Berikut ini diuraikan tentang program utama dari sistem yang dirancang. Adapun modul program adalah sebagai berikut :

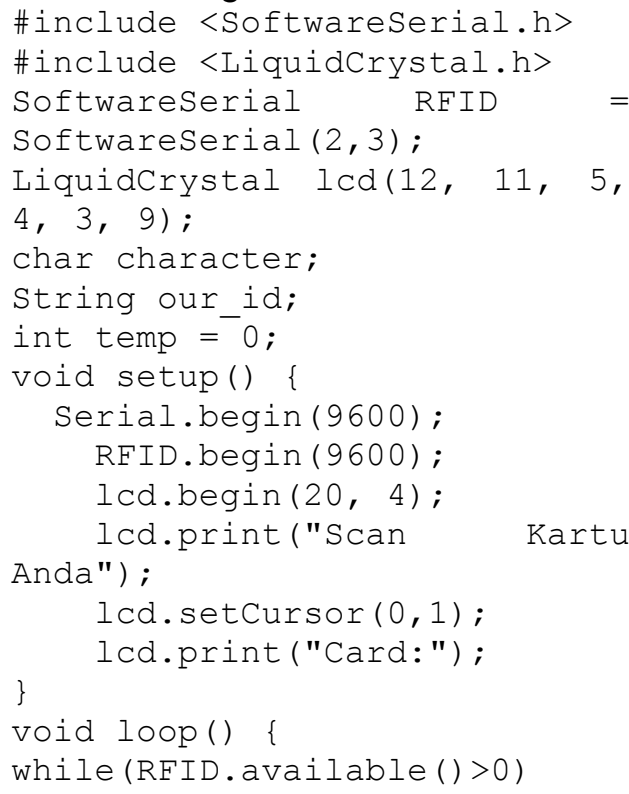

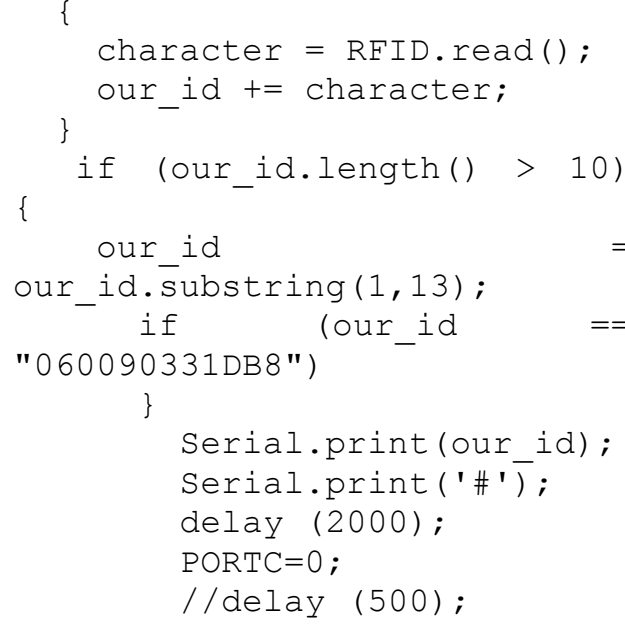

\section{HASIL DAN PEMBAHASAN}

Adapun langkah yang harus dilalui dalam pemrograman Arduino Uno adalah sebagai berikut :

1. Jalankan aplikasi Arduino dengan mengklik ganda ikon Arduino, sehingga muncul tampilan seperti gambar 12 .

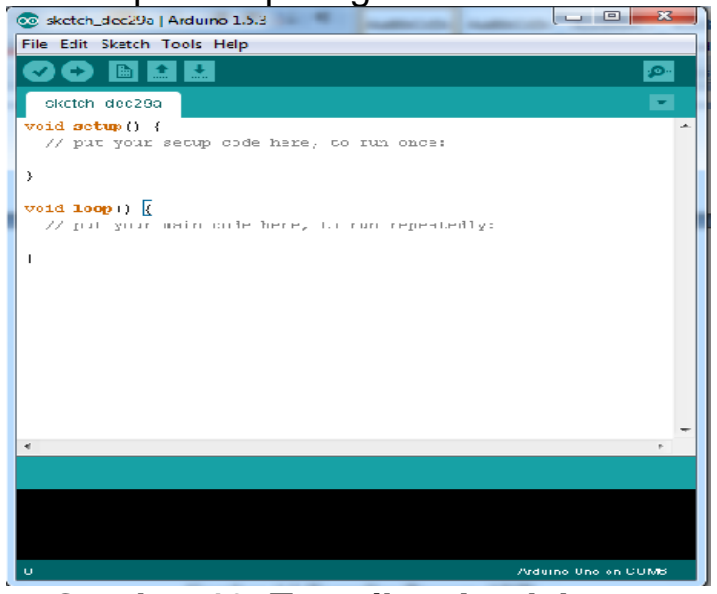

\section{Gambar 13. Tampilan Jendela Arduino}

2. Lakukan pengetikan program, kemudian simpan program Anda dengan memilih "File $\rightarrow$ Save"seperti gambar 13. 


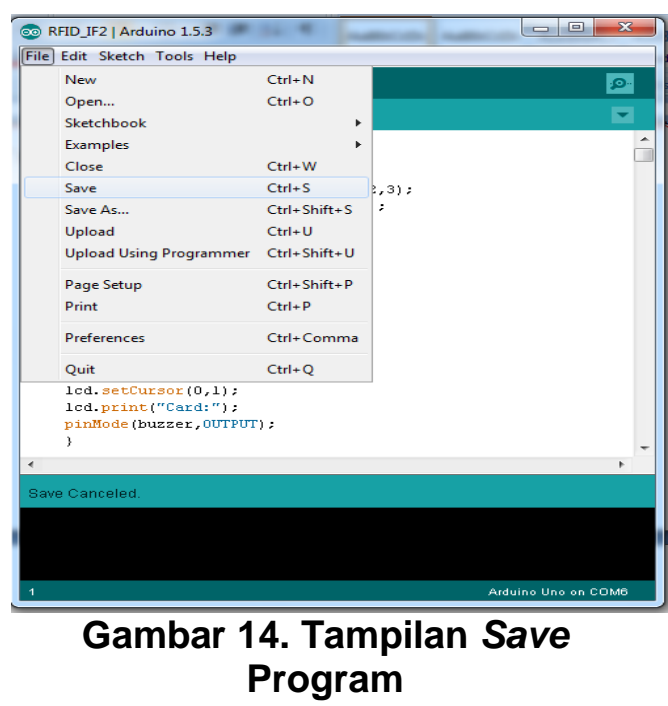

3. Setelah itu kompilasi program yang telah diketik dengan memilih Sketch $\rightarrow$ Compile, seperti gambar 14 .

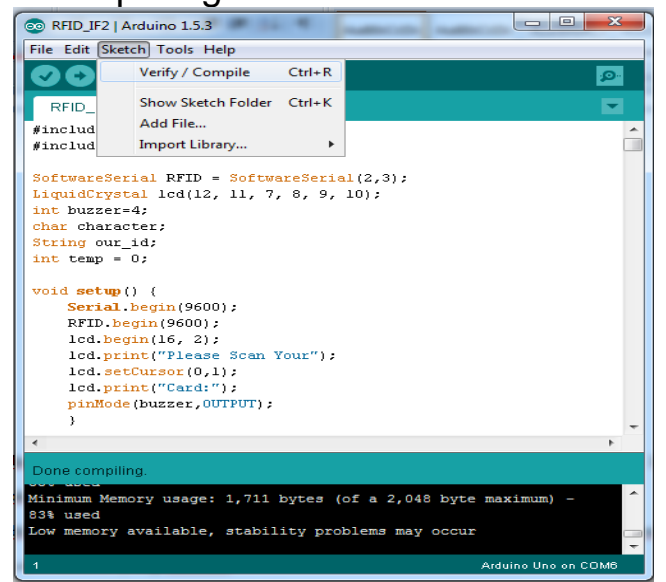

Gambar 15. Tampilan untuk Compiler pada Arduino

4. Langkah selanjutnya adalah proses uploadfile yang telah dikompilasi tersebut ke dalam mikrokontroler ATMega328/Arduino Uno.

5. Pilih 'Upload', tampil gambar seperti 15.

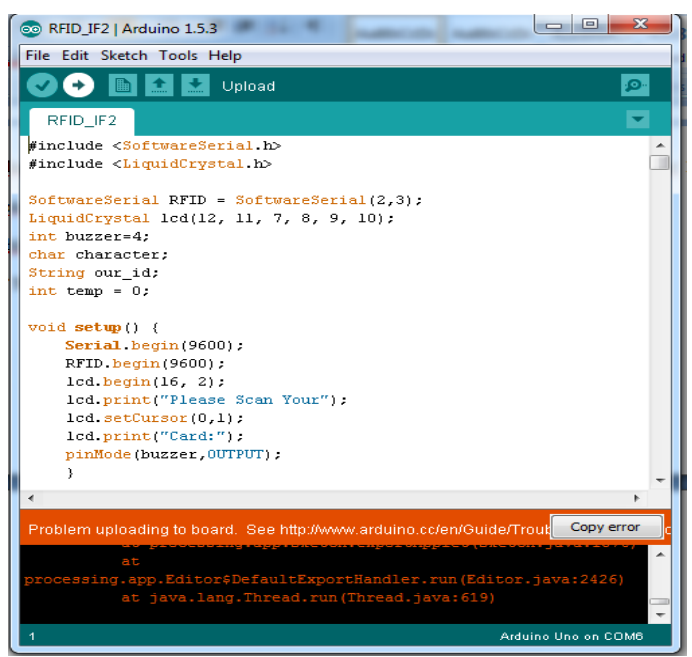

Gambar 16. Tampilan Upload pada Arduino Uno

6. Setelah program diupload ke Ardunio Uno, Arduino tersebut siap digunakan pada sistem yang dirancang yang akan ditampilkan ke LCD.

7. Jalankan aplikasi Bascom AVR dengan mengklik ganda ikon Bascom, sehingga muncul tampilan seperti gambar 16 .

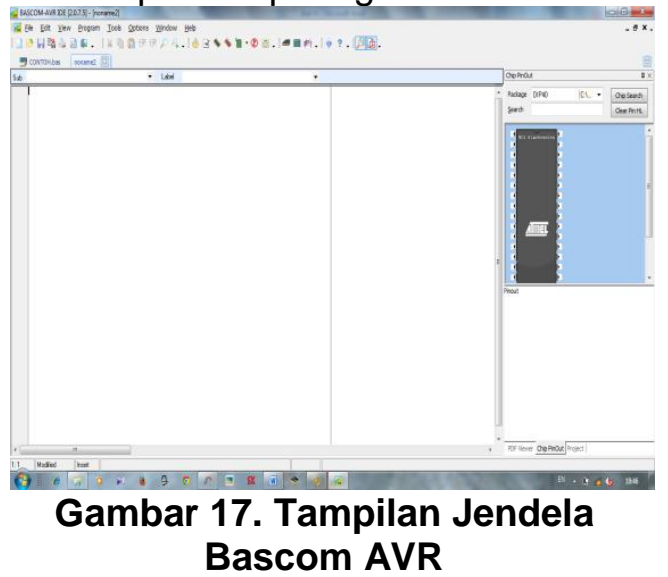

8. Lakukan pengetikan program, kemudian simpan program Anda dengan memilih "File $\rightarrow$ Save"seperti gambar 17. 


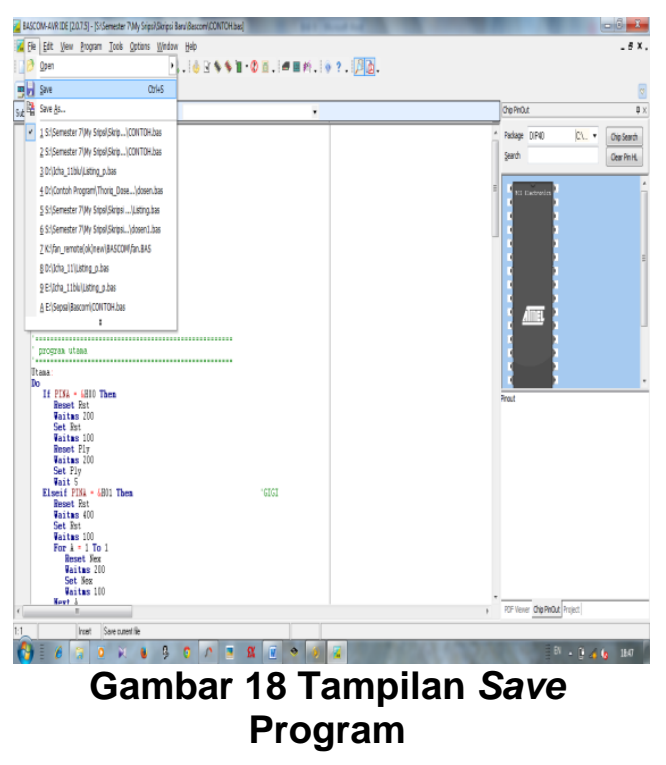

9. Setelah itu kompilasi program yang telah diketik dengan memilih Program $\rightarrow$ Compile, seperti gambar 18.

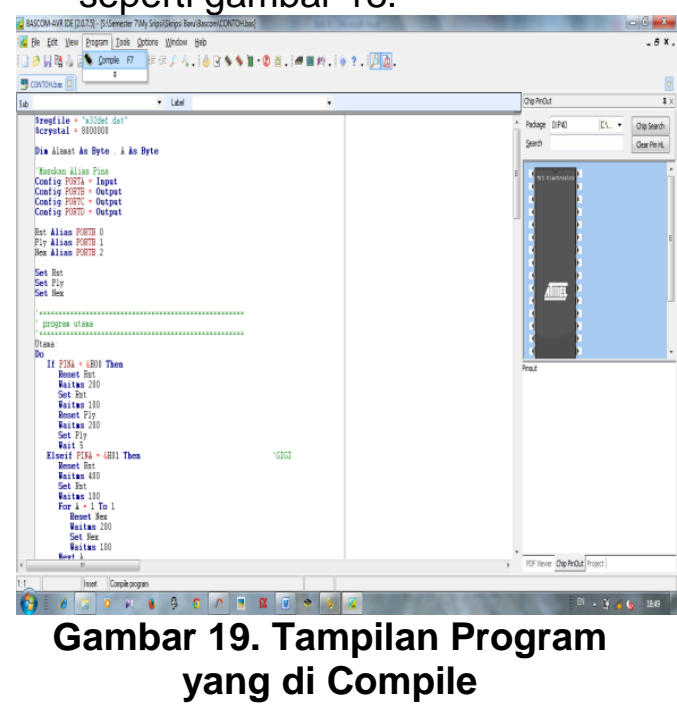

10. Langkah selanjutnya adalah proses uploadfile yang telah dikompilasi tersebut ke dalam mikrokontroler ATMega32A.

11. Pilih 'Upload', tampil gambar seperti 19.

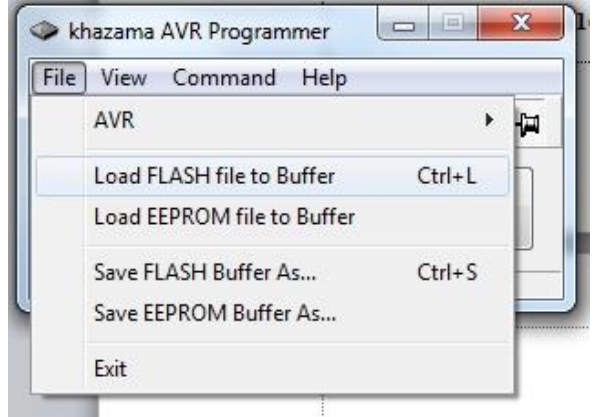

\section{Gambar 20. Tampilan Program yang di Upload}

12. Setelah program diupload ke Atmega32, Atmega32 tersebut siap digunakan pada sistem yang dirancang yang akan Suara.

\section{Pengujian Alat}

Langkah-langkah untuk menjalan alat yang telah dibuat gambar berikut:

1. Menghubungkan alat ke arus.

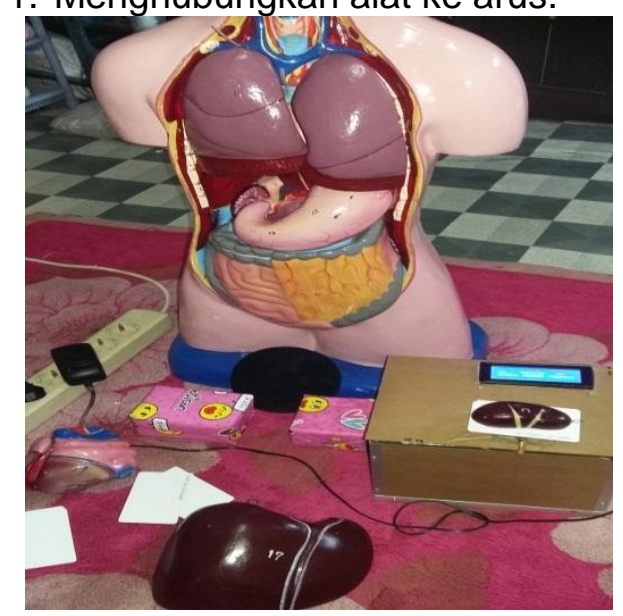

Gambar 21 Menghubungkan Alat ke Arus

2. Setelah alat nyala, maka LCD akan menampilkan informasi sebagai gambar berikut :

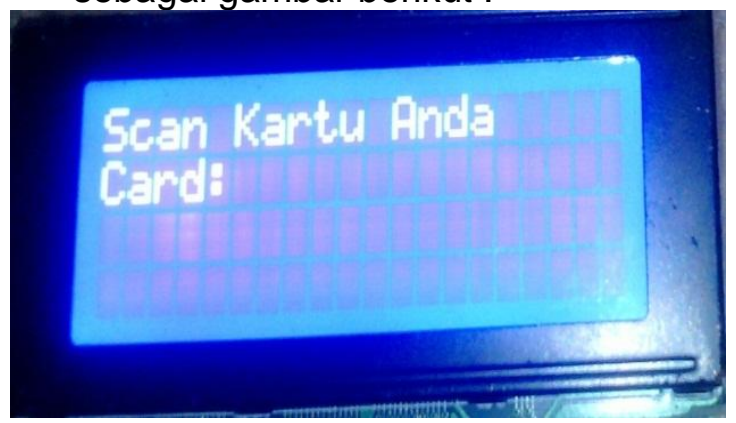

Gambar 22. Tampilan awal LCD 
3. Setelah itu, untuk pembacaan Tag RFID dilakukan dengan mendekatkan Tag RFID ke alat yang telah dibuat. Pembacaan Tag RFID akan ditampilkan ke layar LCD dan Suara aktif sesuai dengan ID yang telah ditentukan.

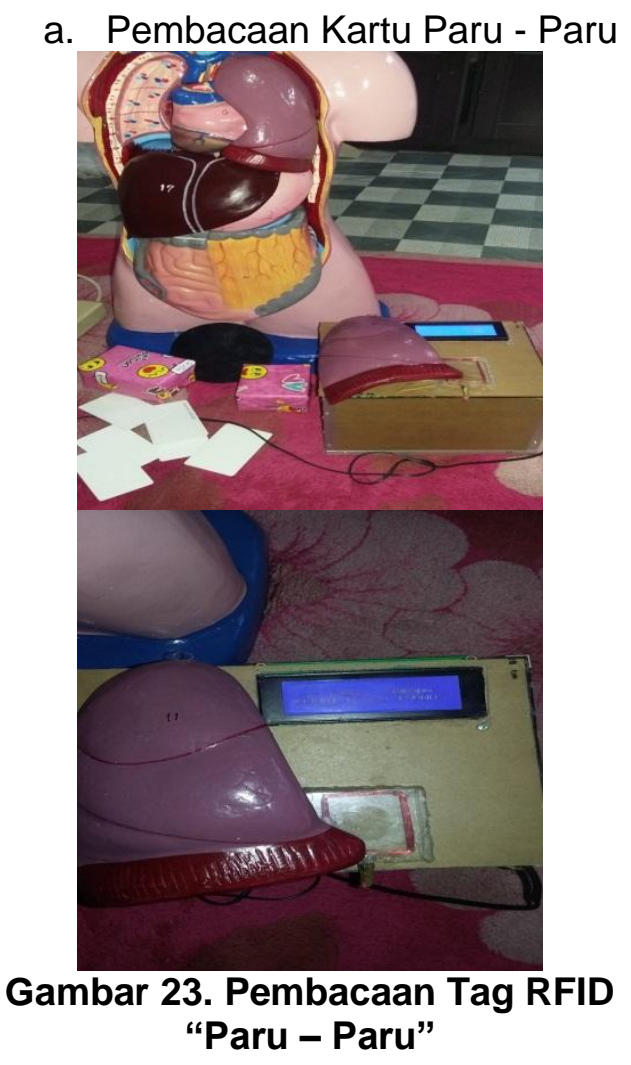

b. Pembacaan Kartu Lambung

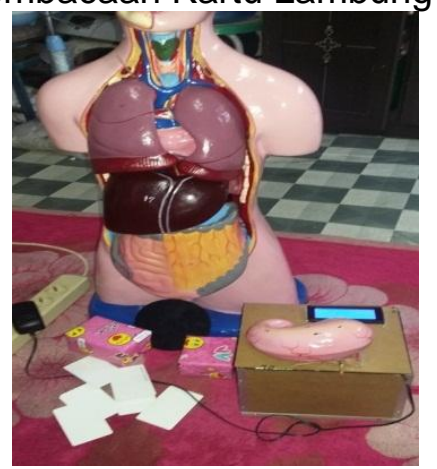

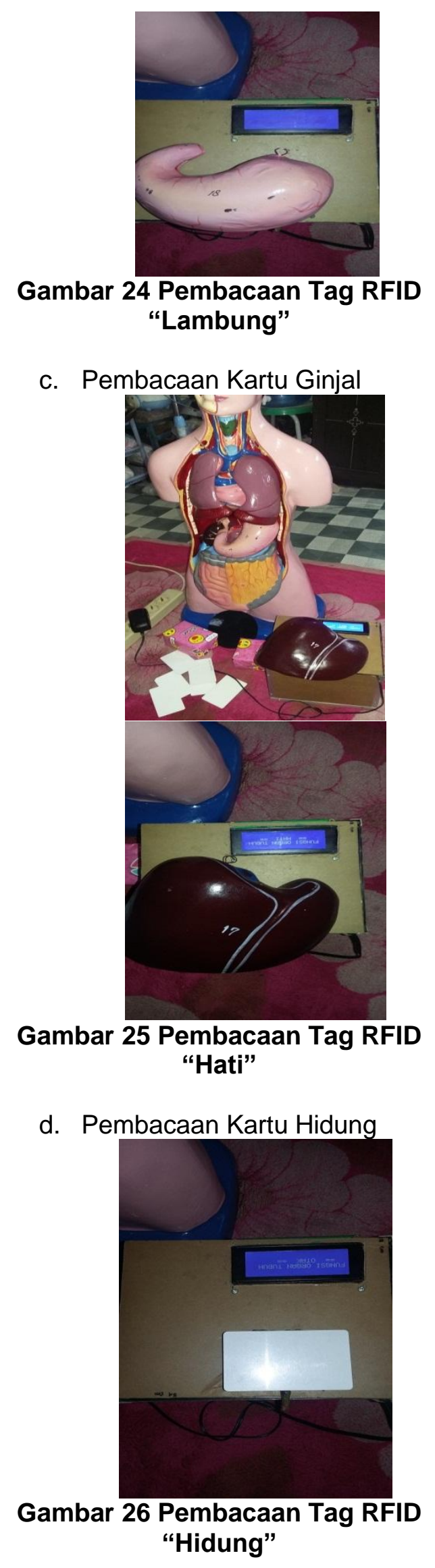

Gambar 25 Pembacaan Tag RFID

d. Pembacaan Kartu Hidung

"Hidung" 

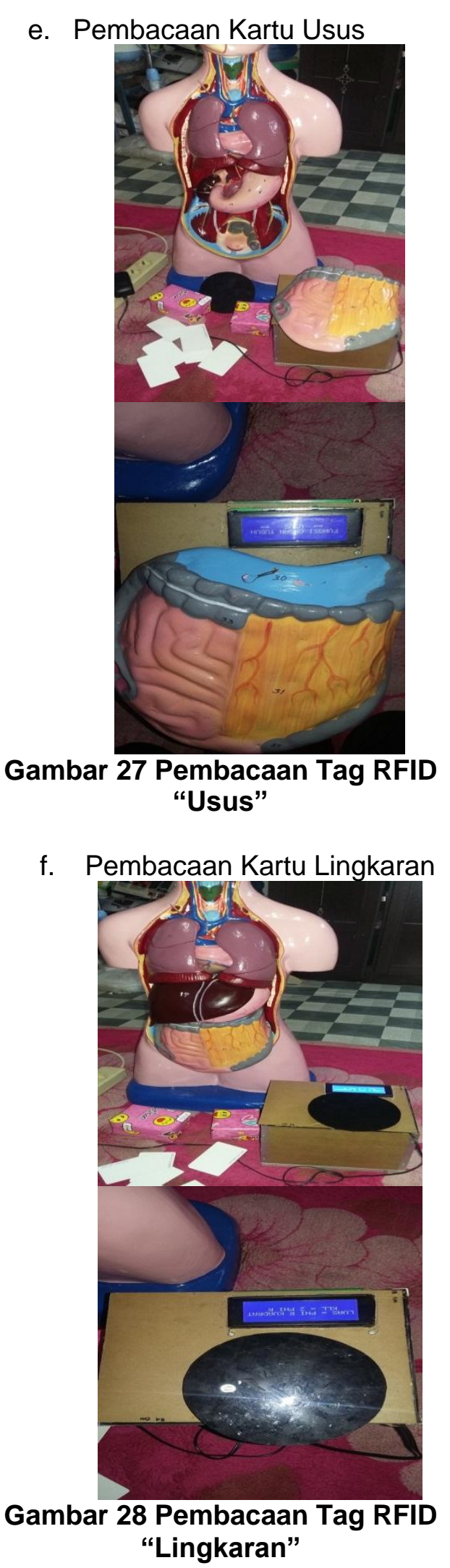

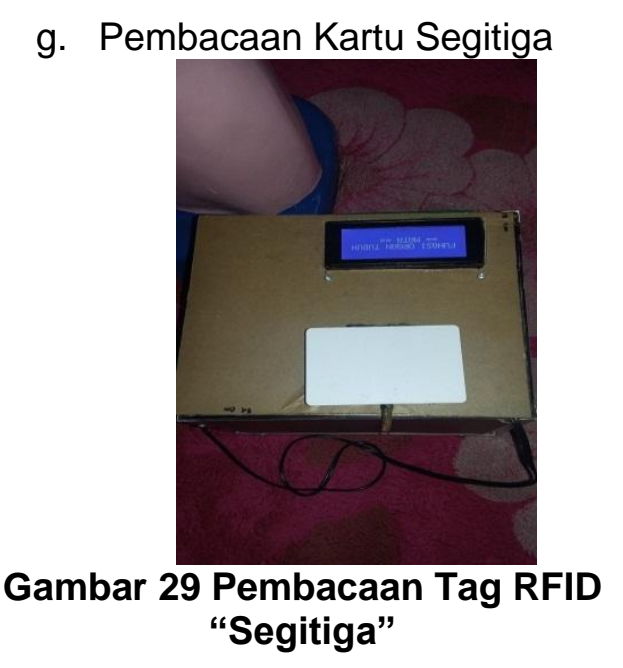

DAFTAR PUSTAKA

[1] Jogiyanto. Sistem Teknologi Informasi.2009

[2] Saputra, Agus.Sistem Informasi Nilai Akademik Untuk Panduan Skripsi. 2012

[3] Suarga.Algoritma

Pemprograman.2012

[4] Setoawan, Arie.Aplikasi Mikrocontroler ATmega 8535 \& ATmega 16 Menggunakan Bascom AVR.2011

[5] Nalwan, Andi.Teknik Rancang Bangun Robot.2012. Yogyakarta : ANDI

[6] www.alldatasheet.com 